\title{
11 A mixed methods engaged study of divergent imaginaries in Bergen's mobility transition
}

\author{
Siddharth Sareen, Devyn Remme, Amber Nordholm \\ and Katinka Wågsæther
}

\section{Commoning and decarbonising mobility in Bergen}

Like Rome with its seven hills, Bergen is set amidst seven mountains on Norway's west coast. Physical geography can be determinative of many things (Marshall, 2016) and transport is no exception - unlike a flat bicycle mecca like Copenhagen, Bergen's old city centre is inaccessible from many suburbs by bicycle but within quick reach using motor transport through mountain tunnels. Little wonder that an urban planner at our seminar remarked and visualised that the mountains are Bergen's most powerful planners (see Figure 11.1). The mountains not only condition mobility flows; they also drive preferences for where inhabitants reside, with high demand for real estate on mountain slopes angled to get more sunlight in Europe's rainiest city on a northerly latitude.

Yet it is not mountains alone that determine mobility patterns, as is apparent in one of Bergen's claims to fame: in the late 2010s it became arguably the global electric car capital. Diffusion of electric automobility, helped along by a generous all-inclusive national package of incentives, made Norway a world leader in electric vehicle (EV) rollout, with 2020 marking a year with considerably more EVs sold than cars with internal combustion engines (Norsk Elbilforening, 2021; Norwegian Road Federation, 2021). In 2018, Bergen took over the mantle as the city with the highest penetration of EVs per capita from Oslo at the annual weeklong political gathering of Norway in the southern city of Arendal. ${ }^{1}$ While this title changes hands annually among Norwegian cities, EV diffusion in Bergen remains high relative to both national and global averages. This shift has been enabled in large part through financial subsidies (for EVs) and taxes (for fossil fuel cars).

The same logic of incentives can be extended to the more complex issue of multi-modal transport. Bergen municipality has signed an Urban Growth Agreement, circumscribed by the federal Zero Growth Objective, which calls for "zero growth" ("null vekst" in Norwegian) in urban car traffic while prioritising public and non-motorised transport. Accordingly, urban planners are working to reduce car parking spaces in the city centre, increase use of car sharing schemes, expand the light rail ("Bybanen"), increase bus services including electric buses and enhance bicycling infrastructure. In 2021, an old tram route 


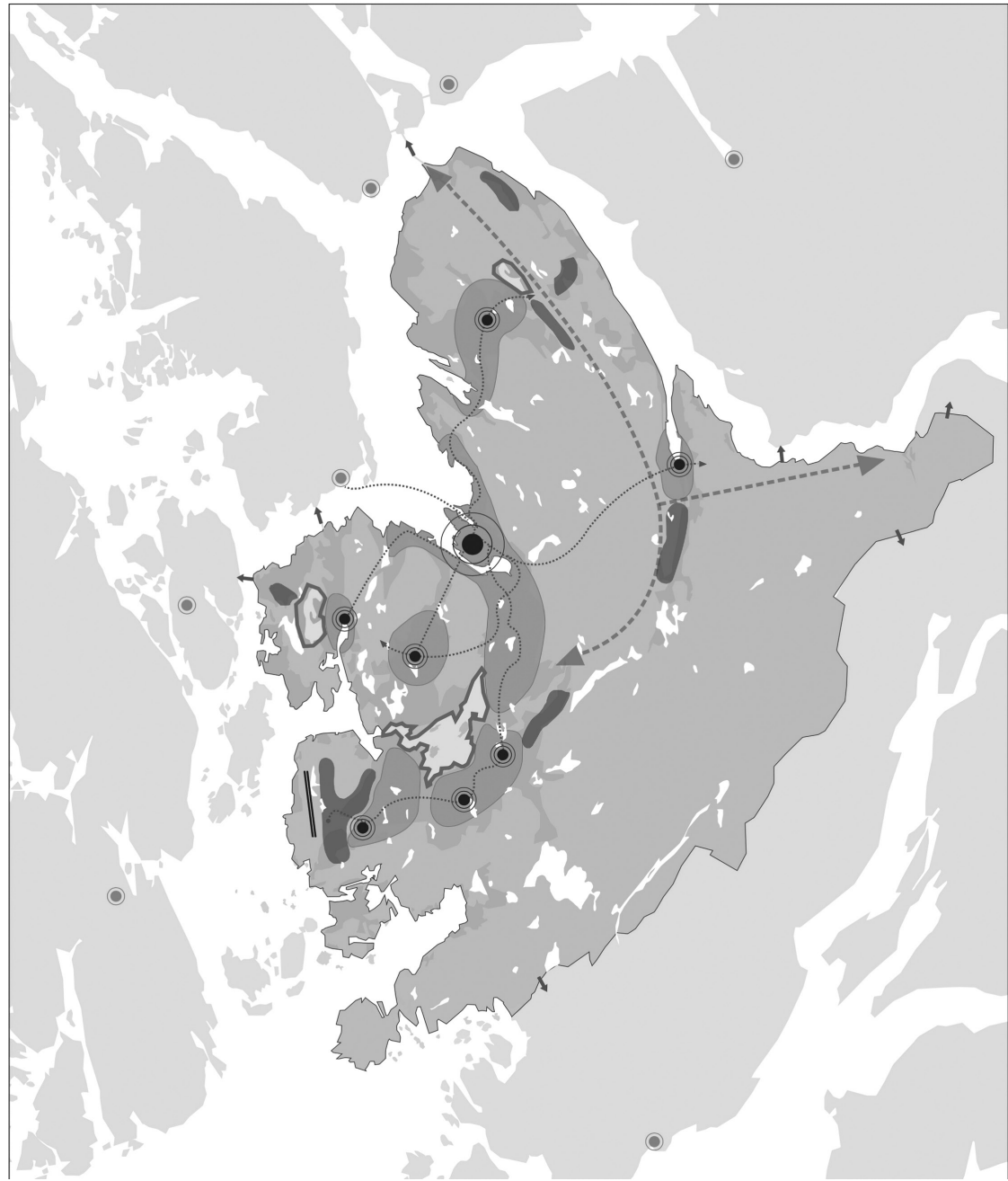

Figure 11.1 A planner's map shows that the mountains are Bergen's most powerful urban planners. Source: Bergen municipality, municipal spatial plan 2018.

was re-established after decades; an important symbolic nod to a shifting sociotechnical imaginary of urban mobility. It runs adjacent to Bergen's first car-free zone of Møhlenpris, and the municipality is actively pursuing multiple car-free zones in the suburbs.

The guiding principle here is to reduce greenhouse gas emissions (principally carbon) sourced from urban transport, which is one of the major emitting sectors in a Norwegian context where most urban energy use relies on electricity which is predominantly generated through hydropower. The most straightforward way to decarbonise urban transport is to electrify it. This reduces energy 
demand compared to fossil fuel sources, as electric transport today is already more energy efficient (Asdrubali et al., 2018). In order to avoid a dramatic increase in demand on the electric grid, it is important to incentivise greater use of public transport solutions rather than individually powered electric cars and to activate complementary low-energy mobility solutions like electric bicycles and e-scooters. Such shifts have the advantage of freeing up valuable urban space from cars. Car-centric planning, theorised by mobility scholars as a scarcity-producing regime (Hoeschele, 2010), can be summarised as the production of unlimited wants in a world of limited resources. In response to these scarcity concerns, scholars present the commons as an alternative to privatisation. "Commoning" transport entails collective decision-making and the allocation of resources such as urban space and transportation facilities to public usage (Nikolaeva et al., 2019). The street, seen as a commons, frames automobility as an enclosure of public space for private use. Accordingly, redistributing space from cars to less resource-intensive modes represents a "communing" project (ibid). But the socio-technical imaginary of mobility in a Norwegian context is heavily biased towards automobility (Eriksen, 2020), with high car ownership rates, which makes this fundamental shift challenging to govern and incentivise (Kester et al., 2020). Indeed, Bergen's local elections in 2019 witnessed a strong performance by a political party premised on opposition to congestion fees in the city centre, finishing third with a $16.7 \%$ vote share compared to the Green Party in fourth place with a vote share of 9.9\% (Bergen Municipality, 2019).

This chapter draws on a mixed methods study to advance an understanding of how socio-technical imaginaries are shaping and being shaped in what is in some ways a world-leading example of urban mobility transitions. This is particularly significant for the Nordic and Baltic context, where policy insights gleaned are transferable across cities and of high relevance in the near future. We draw on small-scale surveys with both public transport users and car drivers, expert interviews with diverse sectoral stakeholders, focus groups with transport users and discussions during a public seminar on just mobility transitions and a closed workshop with Bergen's mobility planners. We show that the main argument emerging from this study is for urban and mobility planners to explicitly address mobility transition politics and justice in public messaging and to change the embodied routines of transition planning and implementation to cohere around enabling socially inclusive mobility futures during rapid sectoral decarbonisation. Thus, we call to heighten explicit ambition to reshape the socio-technical imaginary of mobility through altered bureaucratic routines of urban governance.

We proceed as follows: a short theoretical section features a review of literature on socio-technical transitions and imaginaries, and on energy justice. A section on our methodology comes next, followed by empirical analysis that sequentially utilises our mixed methods data. A discussion places our findings more abstractly within an energy justice framework. We conclude with key policy insights for commoning mobility in Bergen and other transitioning Nordic and Baltic cities. 


\section{Transition politics, socio-technical imaginaries and energy justice}

During the 2010s, the urgency of low-carbon transitions such as decarbonisation of the urban mobility sector has become a major issue on policy agendas (IPCC, 2018). Following the Paris Agreement of 2015, this is reflected, for instance, in the Sustainable Development Goal (SDG) 11 on sustainable cities and communities (Nikulina et al., 2019), in the ambitions and membership requirements of global city networks such as C40 Cities and the Covenant of Mayors (Croci et al., 2017) and in cities' own carbon budgets and commitments (Phdungsilp and Martinac, 2013; Vagnoni and Moradi, 2018) such as Bergen's Urban Growth Agreement (Haarstad, 2019).

These targets and concomitant real-world activities have prompted rapid growth in scholarship on socio-technical transitions, evident in the rise to prominence of e.g., the Sustainability Transitions Research Network and its flagship journal Environmental Innovation and Societal Transitions (established 2011) and the influential journal Energy Research $\mathcal{E}$ Social Science (established 2014). Seminal (e.g., Markard, Raven and Truffer, 2012) and more recent agenda setting contributions (e.g., Köhler et al., 2019; Sovacool et al., 2020) and synthesis reflections (e.g., Van Veelen et al., 2019) showcase the breadth and depth of this established field of scholarship. Within this vast field, there is a rich focus on urban transitions (e.g., Loorbach et al., 2016; Frantzeskaki et al., 2017), including a direct concern with a range of socio-technical pathways for urban mobility transitions and the roles of diverse stakeholders (Marletto, 2014; Axsen and Sovacool, 2019). These studies have shown that challenges linked with mobility transitions are inherently political, dynamic and contingent upon the political economy of urban mobility sectors. In other words, it is important to understand how government administrations, politics and the economy interact and influence each other, which impacts how mobility manifests in a city. Scholars emphasise that actors play embedded roles and mobilise embodied understandings that proliferate in a variety of ways, through their lived experience, received wisdom, inertial conventions and other cities' examples.

Within this rich tapestry of networked governance of mobility transitions, we locate our focus in relation to two distinct trends in scholarship: evolving socio-technical imaginaries of urban mobility and the impact of transitions on energy justice. Mutter (2019) employs the concept of socio-technical imaginaries to the mobility sector using the Swedish case of Linköping to examine contrasting visions of electric and biogas-based public transport. We share this concern with imaginaries of future low-carbon mobility and envisioned socio-technical pathways, but distinct from this study, we adopt a focus on justice and approach this in an explicitly socio-spatial manner.

Energy justice draws from environmental justice by acknowledging the uneven and inequitable distribution of environmental effects, such as pollution and climate change (Bullard and Johnson, 2002; Agyeman, Bullard and Evans, 2002). Taking this idea further, energy justice scholarship supports a targeted systems 
focus, which is better oriented for policy uptake and real-world impact (Jenkins, 2018). Closely related to energy justice is mobility justice research, wherein scholars consider transport, environmental and energy justice to be intertwined and co-constituted (Verlinghieri and Schwanen, 2020; Mullen and Marsden, 2016; Sheller, 2018; Urry, 2006). Their analytical approaches span attention to underlying socio-cultural, political and economic structures that shape policy and practice (Kębłowski and Bassens, 2017; Mattioli et al., 2020) to focus on everyday practices and embodied knowledge (Doughty and Murray, 2016; Jensen, 2010; Waitt and Harada, 2012). Similar to energy justice researchers, mobility justice scholars adopt a practical approach that extends beyond describing and analysing social inclusion. They endeavour to materialise transitions that create more just cultures of mobility.

In this study, we unpack the justice implications of urban mobility transitions through attention to what changing imaginaries imply in terms of use of urban space. Following Nikolaeva et al. (2019), we regard a justice lens as a push for commoning mobility, foregrounding shared resources and participatory processes in response to scarcity. This has deep resonance with Baltic urban contexts, whose mobility transitions have complex legacies and face current challenges (Grava, 2007). To this focus on mobility transitions, we add what is by now a relatively mainstream understanding of energy justice that links sustainability to social and spatial equity. Although this richly developed field has more to offer (e.g., Jenkins et al., 2016; Sovacool and Dworkin, 2015; Bouzarovski and Simcock, 2017), we share the concern of Wood and Roelich (2020) to advance situated understanding of what is at stake, namely competing socio-technical imaginaries of mobility futures.

To this end, a basic adaptation of what Fraser (2009) defines as the distributive, procedural and recognition-based aspects of justice are sufficient to explicate our concern with energy justice. We frame the allocation of benefits and disadvantages in society and across space under distributional justice (McCauley, 2018; Sovacool et al., 2019). Procedural justice concerns fairness in how transitions are implemented, thus serving to evaluate participation (Yenneti and Day, 2015). Justice as recognition acknowledges marginalised or vulnerable people who may experience worsened conditions as a result of the low-carbon transition (Sovacool et al., 2019). Accordingly, we structure the empirical analysis of our mixed methods data through the energy justice dimensions of distributive, procedural and recognition-based justice in Bergen's mobility transition, as a means to unpack the changing nature of this socio-technical imaginary of urban mobility.

While the envisaged sectoral shifts are legitimated in terms of these dimensions to Bergen's commuting publics, our explicit consideration devotes attention to which mobility users' interests are represented, in what manner, at what forum and which ones are potentially absent. We subsequently discuss the implications that these justice aspects have on the particular way in which urban planners, practitioners and politicians may productively regard the challenge of such a transition: as the explicit reshaping of the socio-technical imaginary of mobility to a more just way of using and moving through urban space. This analysis 
advances an emerging push in the socio-technical transitions literature for a more closely wedded understanding of energy vulnerability and transport as referring to highly overlapping users (Robinson and Mattioli, 2020; Martiskainen et al., 2020).

\section{Methodology}

This chapter is based on data collected and analysed during the "Just Mobility Transitions" and "Responsive Organising for Low Emission Societies" projects, where our team studied how rapid changes to decarbonise mobility impact social justice in Bergen. In combination with a literature and document review, we organised a public seminar, co-facilitated a closed workshop with municipal actors, designed and ran two linked mini-surveys and conducted 19 expert interviews.

The surveys were developed with two target groups in mind. First, public transport users (labelled the "public transport survey") and second, those who mainly commute by private vehicle (referred to as "driver survey"). There were overlapping and customised questions in each, and here we have conducted a combined analysis focusing on the overlapping questions. Together these yielded a total of 162 responses. The public transport survey featured 18 questions and the driver survey featured 21 questions. These covered commuting habits, perceptions of fairness or (dis)agreement with public transport financing and costs and concerns for climate change. We considered geographic, social and technical dimensions such as location, income, public understanding and digital literacy. The surveys were anonymous and took three to six minutes to complete.

The public transport survey was conducted by a researcher stationed at public transport hubs in Bergen. The researcher approached commuters who then had the choice of completing a paper version or scanning a $Q R$ code with their phone to complete the questionnaire online via their mobile smartphones. A total of nine 90-minute sessions across three locations yielded 113 responses. The initial approach of the driver survey was similar, with a researcher stationed at parking houses in the city centre. Four sessions across two locations yielded 21 responses. This approach was discontinued when researchers experienced persistent unapproachability of drivers and awkwardness, exacerbated by concerns related to the pandemic circumstances which had heightened by this point in time in Bergen. Instead, we requested Facebook pages and groups related to urban mobility to post a survey link to their members, and it was subsequently shared by the City Centre company (Bergen Sentrum) and City Development (Byutvikling i Bergen) group on their respective Facebook pages. This yielded another 28 responses.

The public seminar featured contributions from Bergen's urban planners, private sector mobility actors (a digital mobility solutions start-up Alpha Venturi and Bergen's largest car sharing company Bildeleringen) and local academics. While the pandemic circumstances restricted participation and the form of engagement (i.e., the format was limited to plenary talks and discussions with partially digital participation), there was strong attendance with over 50 participants ranging 
from planners and policymakers to practitioners and academics with an interest in urban mobility transitions.

The municipal workshop was a collaboration between the Centre for Climate and Energy Transformation at the University of Bergen and Bergen's municipal office for cycling and mobility. The need for such a workshop emerged through discussions between the two units around the roll-out of Car-Free Zones (CFZs), for which the latter unit is responsible. Convened in October 2020, the workshop aimed to generate and discuss inputs from a variety of municipal actors and mobility researchers on the next steps for CFZ development. This featured a brainstorm on the why, what and how of this municipal initiative, with a mandate to expand these zones from inner city areas to outer suburbs. Eleven municipal officials and five researchers took part in the full-day workshop.

The expert interviews were semi-structured and mainly conducted virtually in line with pandemic measures. The 19 interviewees included local and county politicians (three), municipal officials from Bergen and neighbouring municipalities (eight), a representative of the Norwegian State Housing Bank, private sector property developers and architects (four) and a civil society representative, a researcher and a journalist each with expertise on urban mobility. Interviews focused on issues linked with Bergen's broader mobility trajectory, mobility justice and explicit details of the mobility system and changes underway. The interviews aimed to bring to the fore perceptions, contestations, challenges and system components. We undertook basic data analysis using a combined deductive and inductive approach, referred to as an abductive approach, and by triangulating among four project team members to ensure a robust analytical process. This took the form of weekly meetings and detailed written analyses as we drafted this chapter.

The next section presents our empirical analysis. It draws sequentially on mixed methods data.

\section{Empirical analysis of mixed methods data on Bergen's mobility transition}

To structure our empirical analysis, we first report the results of the public transport and driver surveys as a baseline on issues relevant to a just mobility transition in Bergen. Next, we deepen insights on key issues by drawing on discussions during the public seminar and the municipal workshop. Finally, we discuss specific aspects that emerged from expert interviews with salience for social justice and socio-technical imaginaries of Bergen's mobility transition.

\section{Survey results}

Our 162 survey respondents were on the younger end of the spectrum, between 18 and 40 years old, with a quite even gender split. 75/162 owned cars, of which 31 had petrol cars, 25 had electric cars, ten had hybrid cars and nine owned diesel cars (see Figures 11.2 and 11.3). 


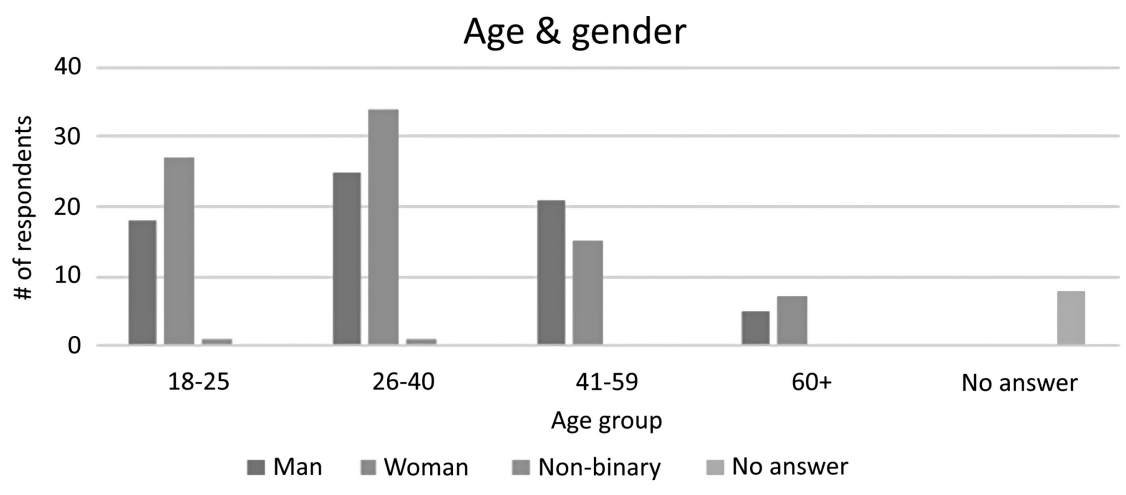

Figure 11.2 Respondent distribution by age and gender.

\section{Car ownership}

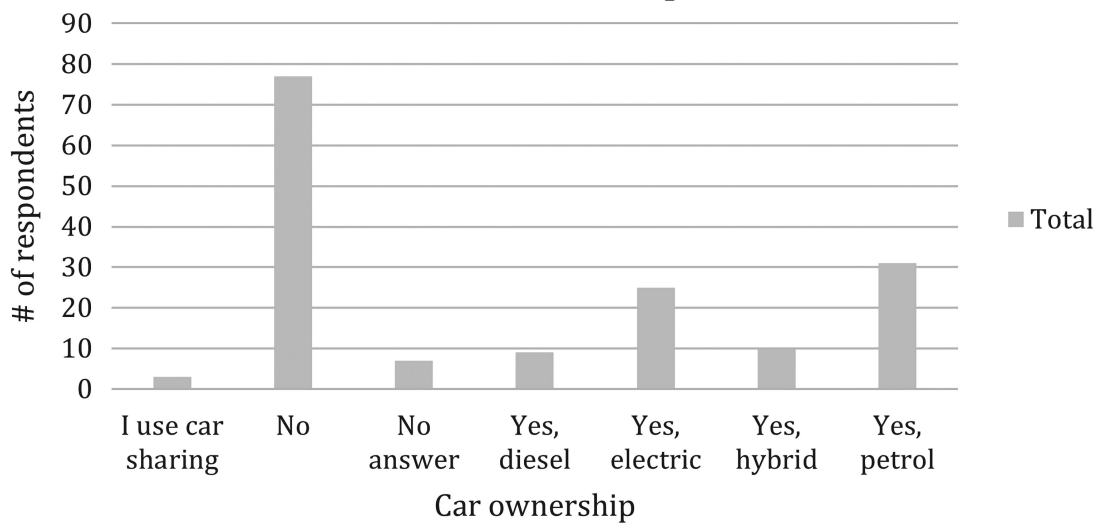

Figure 11.3 Respondent distribution by car type ownership.

Our small-scale survey offers good scope for reflections within its limited scope. Respondents overwhelmingly agreed with funding public transport by imposing tolls charges on car users (141/162) and through tax revenue (151/162) as fair (see Table 11.1). Most were favourably inclined to the prospect of free public transport (131/162) and stated that climate concerns impact their modal choice (145/162). These findings suggest that citizens' transport imaginaries are wellaligned with Bergen's urban planning vision of decarbonisation and prioritisation of public and non-motorised transport over individual cars.

To discern if this imaginary varies by car ownership, we filtered responses by car ownership. Table 11.2 shows that percentages are quite similar across the 75 car owners and 87 non-car owners. Both categories are highly positive. Yet noncar owners show a slightly higher proportion of positive responses, notably on the use of toll charges to finance public transport, where $91 \%$ are positive compared 
Table 11.1 Overview of responses related to climate concern, public transport finance, pricing and tolls

\begin{tabular}{|c|c|c|c|c|}
\hline Question & $\begin{array}{l}\text { Negative } \\
\text { response }\end{array}$ & $\begin{array}{l}\text { Positive } \\
\text { response }\end{array}$ & Grand total & $\begin{array}{l}\text { Positive rate } \\
(\%)\end{array}$ \\
\hline $\begin{array}{l}\text { To what extent do climate } \\
\text { concerns influence your choice } \\
\text { of transportation? }\end{array}$ & 17 & 145 & 162 & $90 \%$ \\
\hline $\begin{array}{l}\text { To what extent is it fair for public } \\
\text { transport to be financed by } \\
\text { taxpayers? }\end{array}$ & 11 & 151 & 162 & $93 \%$ \\
\hline $\begin{array}{l}\text { Toll charges previously financed } \\
\text { roads and bridges. More recently, } \\
\text { more of these have financed } \\
\text { public transport. To what extent } \\
\text { is this fair? }\end{array}$ & 21 & 141 & 162 & $87 \%$ \\
\hline $\begin{array}{l}\text { Some cities have made public } \\
\text { transportation free. Is this a good } \\
\text { use of taxpayers' money? Do you } \\
\text { agree or disagree? }\end{array}$ & 31 & 131 & 162 & $81 \%$ \\
\hline
\end{tabular}

Table 11.2 Percentage of positive responses per car ownership

\begin{tabular}{lll}
\hline Question & $\begin{array}{l}\text { Owns a car } \\
\text { (\% of } n=75)\end{array}$ & $\begin{array}{l}\text { Does not own a car } \\
\text { (\% of } n=87)\end{array}$ \\
\hline $\begin{array}{l}\text { To what extent do climate concerns influence your } \\
\text { choice of transportation? }\end{array}$ & $88 \%$ & $91 \%$ \\
$\begin{array}{l}\text { To what extent is it fair for public transport to be } \\
\text { financed by taxpayers? }\end{array}$ & $96 \%$ & $91 \%$ \\
$\begin{array}{l}\text { Toll charges previously financed roads and bridges. } \\
\quad \begin{array}{l}\text { More recently, more of these have financed public } \\
\text { transport. To what extent is this fair? }\end{array}\end{array}$ & $93 \%$ \\
$\begin{array}{l}\text { Some cities have made public transportation free. Is } \\
\text { this a good use of taxpayers' money? Do you agree } \\
\quad \text { or disagree? }\end{array}$ & $79 \%$ & $83 \%$ \\
\hline
\end{tabular}

to $83 \%$ of car owners. Hence, while people broadly agree on these aspects of the Bergen transport imaginary, non-car owners are slightly more aligned with the city's vision.

We next consider the extent to which climate concerns shape modal choice. Table 11.3 shows all available options and differentiates respondents by car ownership. Again, we find minimal differences across categories, with a slightly higher rate of climate concern among non-car owners. Car owners have higher proportions in the two least concerned categories ("not at all" and "to a small extent"), whereas non-car owners have a slightly higher proportion in the categories that show greater concern, with one exception: car owners have a slightly higher proportion of people who state climate concern as driving modal choice "to a very large extent" (13\% compared to 10\%). 


\section{Siddharth Sareen et al.}

Table 11.3 To what extent do climate concerns influence your choice of transportation?

\begin{tabular}{lll}
\hline & $\begin{array}{l}\text { Owns a car } \\
(\% \text { of } n=75)\end{array}$ & $\begin{array}{l}\text { Does not own a car } \\
(\% \text { of } n=87)\end{array}$ \\
\hline Not at all & $12 \%$ & $9 \%$ \\
To a small extent & $21 \%$ & $18 \%$ \\
To some extent & $41 \%$ & $44 \%$ \\
To a large extent & $12 \%$ & $18 \%$ \\
To a very large extent & $13 \%$ & $10 \%$ \\
\hline
\end{tabular}

Table 11.4 Main transport mode by extent to which climate concerns drive choice of mode

\begin{tabular}{llllll}
\hline & Not at all & $\begin{array}{c}\text { To a small } \\
\text { extent }\end{array}$ & $\begin{array}{l}\text { To some } \\
\text { extent }\end{array}$ & $\begin{array}{c}\text { To a large } \\
\text { extent }\end{array}$ & $\begin{array}{c}\text { To a very } \\
\text { large extent }\end{array}$ \\
\hline $\begin{array}{l}\text { Car main mode } \\
(\% \text { of } \mathrm{n}=39)\end{array}$ & $18 \%$ & $28 \%$ & $44 \%$ & $5 \%$ & $5 \%$ \\
$\begin{array}{l}\text { Other main mode } \\
(\% \text { of } \mathrm{n}=123)\end{array}$ & $8 \%$ & $17 \%$ & $42 \%$ & $19 \%$ & $14 \%$ \\
\hline
\end{tabular}

We therefore took a closer look at respondents' reported primary mode of transport, running a cross-comparison between the concern for climate in modal choice and the main mode of transport. Although 75 respondents reported owning a car, only 39 reported the car as their primary mode of transport. 123/162 reported other modes - public transport (bus or light rail), bicycling or walking. We then compared those with cars as main mode versus those with other main modes for their responses on the extent to which climate concerns determine transport modal choice. This showed a distinct difference: many respondents who used cars as their main mode stated that climate concerns influenced their modal choice "not at all" (18\%) or "to a small extent" (28\%), while only $5 \%$ reported "to a large extent" and "to a very large extent" each. By contrast, among respondents with non-car main modes, climate concerns influenced this "to a very large extent" (14\%) or "to a large extent" (19\%) for many, while only $8 \%$ stated that climate concerns did "not at all" influence modal choice. Hence, users who mainly use buses, light rail, bicycling or walking tend to factor climate concern into modal choice far more than those who mainly use cars (see Table 11.4).

Among the 123 respondents who reported a non-car primary transport mode, 37 reported car ownership. We compared these 37 respondents' spread of climate concern as driving modal choice with the entire 162 respondent sample. Car owners who do not use these as their primary transport mode exhibit aboveaverage climate concern as an influence on modal choice. Most prominently, $24 \%$ of such respondents report "to a very large extent" compared to the $12 \%$ 
average across all 162 respondents. This indicates that car owners who use their car sparingly are relatively more prone to have climate concerns influence their modal choice than average.

We also broke down climate concern as a factor by car type ownership and found respondents who state a lack of climate concern as a factor across all car types, including electric and hybrid cars. Some electric car owners also responded "to a small extent" (see Figure 11.4). This indicates that climate concerns are not necessarily a major factor behind owning an electric car.

Next, we consider the spread across primary transport modes by car type ownership (see Table 11.5). Among respondents, 56\% of EV owners and $60 \%$ of hybrid owners use the car as their primary mode. Among petrol car owners, this rate drops to $42 \%$, and among diesel car owners to $33 \%$. While the small sample size ( 75 car owners) limits the scope of our claims, findings indicate a greater tendency among fossil fuel car owners to use another primary transport mode, compared to EV and hybrid car owners. While the reason for this is unknown,

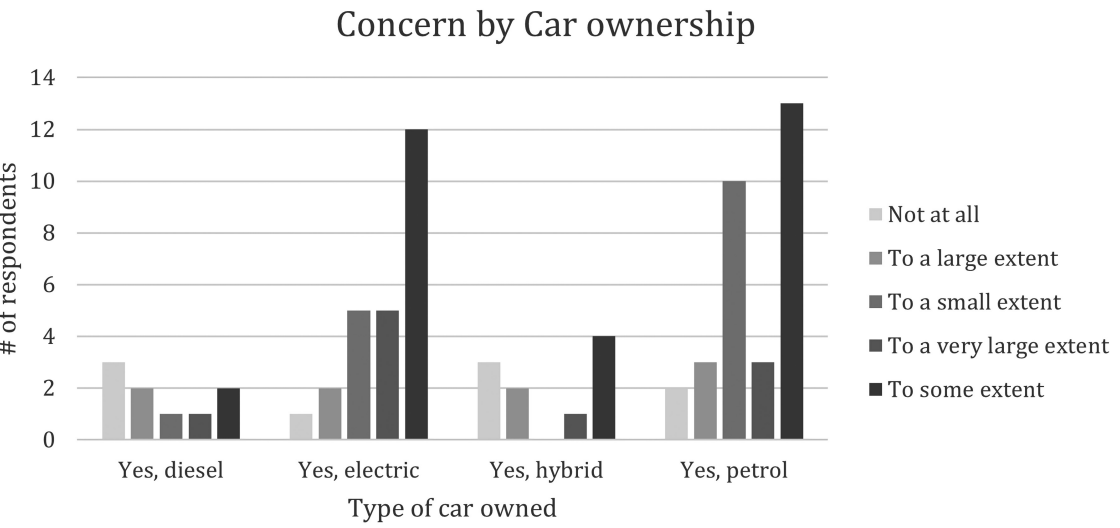

Figure 11.4 Climate concern as a factor in modal choice responses plotted by car type ownership.

Table 11.5 Primary transport mode by car type ownership

\begin{tabular}{llllc}
\hline & $\begin{array}{l}\text { Yes, diesel } \\
(\% \text { of } n=9)\end{array}$ & $\begin{array}{l}\text { Yes, electric } \\
(\% \text { of } n=25)\end{array}$ & $\begin{array}{l}\text { Yes, hybrid } \\
(\% \text { of } n=10)\end{array}$ & $\begin{array}{l}\text { Yes, petrol } \\
(\% \text { of } n=31)\end{array}$ \\
\hline Bike & $11 \%$ & $12 \%$ & & $6 \%$ \\
Car & $33 \%$ & $56 \%$ & $60 \%$ & $42 \%$ \\
$\begin{array}{l}\text { Combination } \\
\text { e-bike }\end{array}$ & $11 \%$ & & $10 \%$ & \\
e-scooter & $22 \%$ & $8 \%$ & & \\
$\begin{array}{l}\text { No answer } \\
\text { Public transport }\end{array}$ & $22 \%$ & $4 \%$ & $10 \%$ & $45 \%$ \\
Walking & $12 \%$ & $20 \%$ & $6 \%$ \\
\hline
\end{tabular}


Table 11.6 Car owners with financial ease or financial difficulty versus car type ownership

\begin{tabular}{lll}
\hline & Ease & Difficulty \\
\hline Diesel $(\%$ of $\mathrm{n}=9)$ & $56 \%$ & $44 \%$ \\
Petrol $(\%$ of $\mathrm{n}=31)$ & $61 \%$ & $35 \%$ \\
Hybrid $(\%$ of $\mathrm{n}=10)$ & $70 \%$ & $30 \%$ \\
Electric $(\%$ of $\mathrm{n}=25)$ & $92 \%$ & $8 \%$ \\
\hline
\end{tabular}

one can hypothesise that, given the relatively high climate concern amongst car owners, those with petrol cars tend to limit car usage. We note, however, that other aspects such as higher fuel and toll costs could be confounding factors here.

Finally, we considered car type ownership against personal finances, based on responses to how easy it is to "make ends meet" with one's household income. EV owners exhibited ease in finances, and only $8 \%$ reported some form of difficulty with finances (see Table 11.6). By comparison, $30 \%$ of hybrid car owners reported some form of difficulty, and this rose to $35 \%$ of petrol car owners and $44 \%$ of diesel car owners.

Overall, our survey indicates substantial public support for Bergen's mobility transition, with an appetite for an affordable public transport system financed by taxpayers and car users. This holds across both car owners and non-car owners but with marginally greater support among the latter. The same applies to the extent to which climate concerns influence modal choice, where respondents voice substantial support but non-car owners exhibit a slightly higher proportion.

While respondents did report substantial climate concern, which suggests fundamental alignment with the imaginary of a low-carbon mobility transition, our findings nonetheless show that modal choices are closely linked to financial position. Notably, in some cases EV ownership does not appear to be related to respondents' climate concern.

Thus, our survey captures a link that supports the possibility of a "green buyout": those with greater financial means tend to buy EVs and are more likely to use cars as their primary transport mode than other (non-EV) car owners. This begs the question of how many public transport users, if they could afford EVs - which are becoming more affordable and are still incentivised - might switch to at least partial reliance on automobility in the future. This constitutes a serious concern, considering that a central part of the Bergen mobility transition imaginary is a shift away from private vehicle use to public transport, cycling and walking.

\section{Public seminar and municipal workshop}

Public seminar on just mobility transitions

To facilitate reflective public discussion on these socio-technical imaginaries, we organised a public seminar on the theme of just mobility transitions. Urban 
planners from the municipality presented Bergen's vision of moving away from car-centric mobility towards a city centre with more public space opened up through reduction of car parking spaces, accompanied by the development of CFZs and a more diverse range of public transport services. They emphasised the policy learning they had gained through urban networks and mobility transition efforts of other cities. For instance, experience of multi-modal transport hubs in Belgium had been transposed to "mobilpunkt" in Bergen to facilitate easier connections between Bybanen, buses and the city bicycle sharing scheme. The planners emphasised their efforts to hold urban cafes and other interactive engagement modes to inform action with public needs. They highlighted the example of Møhlenpris, a city centre neighbourhood developed as a prototype CFZ, which we will return to below.

Private sector speakers introduced a focus on the potential of digitisation to assist with mobility transitions. The car sharing company Bildeleringen, the largest such operator in Bergen, pointed out that its cars served the needs of at least eight households on average, thus reducing potential car ownership eight times among its users and consequently freeing up urban space, all enabled through smart card access that allowed users to digitally book and access cars placed at many central points. A speaker from a blockchain start-up Alpha Venturi explained the potential of distributed ledger technologies to enable a mobile wallet, for instance at the mobility hubs, so that users could use the same ticketing system across operators of Bybanen and city buses (already integrated), city bicycles and car sharing schemes.

Discussion with the audience and amongst speakers brought up concerns such as the availability of and ease of access to services (both public transport and car sharing) beyond the city centre. An issue that was especially prominent in public debates on mobility at the time - the introduction of "e-scooters" - was discussed in relation to the spatial regulation of transport. An urban planner explained that the city would pilot "geo-fencing" for these e-scooters, opening up possibilities to introduce incentives and penalties for providers to meet, for instance, certain levels of provision in suburbs while limiting pavement clutter in the city centre by allocating e-scooter parking zones. These developments flagged the importance of inclusion of diverse perspectives and needs, both in the process of developing interventions and in the implementation of specific designs (e.g., of mobility hubs and smartphone applications for mobility maps and ticketing systems), as well as the key concern of mobility transitions benefitting users across the city's socio-spatial profile.

\section{Municipal workshop on CFZs - whose imaginaries?}

It became apparent from the public seminar that CFZs were emerging as a central part of the urban mobility imaginary of Bergen led by the municipality. The showcase project is in Møhlenpris, a neighbourhood that represents the epiphany of a trendy urban sustainable hipster area with popular cafes and a new beach - an imaginary distant from the realities of Bergen's outer suburb. The planners were fully aware that this city centre pilot could not be airlifted over the mountains and 
into the outer suburbs. They were faced with imagining how the distinct planning legacies, milieus and mobility imaginaries of these suburbs could intermesh with the ambitious timeframe of implementing CFZ projects in every suburb, with a pilot due to commence in autumn 2021 and a report identifying areas and plans for each suburb on this basis due by the end of 2022 (Oppedal, 2020).

What CFZs are and how they may be meaningfully adapted to outer suburbs comprised a central focus of the CFZ workshop in October 2020, which we convened with the municipality. The team entrusted with the suburban CFZ project articulated the challenge of choosing a suburb for pilot implementation, without clear local demand for CFZs in any such suburb and in the absence of clarity on what a CFZ would in fact entail. After all, public space was at a premium in the city centre, but what was the imaginary for it in outer suburbs, where placemaking faced completely different challenges? With the top-down mandate to materialise these CFZs not subject to public participation or political intervention, the team was positioned to make an expertise-based decision and to "move quickly" bound by predetermined timeframes. The project team regarded this mandate, however, as accompanied by the potential to create outrage, both in terms of "why here?" and "why not here?" A reflexive process of imagining these spaces with us as researchers and a broad range of municipal workers across relevant units therefore became an essential next step.

To support the first step of pilot selection, our CFZ workshop included preliminary envisioning of outer suburban CFZs. Municipal representatives emphasised participatory processes with local residents as key, noting that these should lead to an outcome, and that actors involved should be taken seriously. Yet, as they also noted, real participation also implied that the municipality needed to partially let go of control over the process. Here, we note a second challenge: facilitating a deep participatory process within a relatively pre-defined, tightly timebound project. The municipality has already placed CFZs within a specific imaginary: a low-carbon future where the privileges of the private vehicle are substantially curtailed. This conflicts with the project team's ability to facilitate a process that enables local residents - who may or may not subscribe to the municipality's overarching imaginary - to engage, stay engaged and feel ownership of the outcome. This specific collaboration with the municipality identified a key concern: would the project team have the opportunity and willingness to let go of some control, giving people choice to a greater extent, or would it apply an approach aimed principally at enrolling people into its low-carbon mobility vision?

We see here that municipal planners are split between their recognition of the need to observe due process with inhabitants and the need to show measurable results that speak to an imaginary of a low-carbon mobility transition. Finding the balance entails the art of juggling voices, priorities and compromises. As a participant put it, picking an "easy" suburb (with some existing street life and scope to create a convivial area) might not convince people that much had been accomplished through a CFZ, whereas picking a "hard" suburb (with a car-centric 
legacy) that could make a major impression ran the risk of failure, which could also be a blow for what the CFZ vision represents.

\section{Expert interviews}

During October-November 2020, we conducted expert interviews on Bergen's low-carbon mobility transition, primarily with City Council members and municipal planners. This allowed us to explore divergent imaginaries evident in political discourse, led by the green and left-leaning City Council coalition on the one side, and by a recently constituted yet large opposition party called "No to more toll roads" (FNB) on the other side. In contrast to the Green Party's dominant voter base in the city centre, where FNB had a vote share below $4 \%$, the latter proved far more popular in the suburbs. This political polarisation reflects the divergent socio-technical imaginaries entangled with the varied socio-spatial realities of mobility and access across Bergen. The municipal planners working to enact the City Council's imaginary find themselves faced with a vocal minority of FNB supporters, amongst whom an oppositional imaginary elides persistent and cheap car use with socioeconomic equity.

An FNB representative we interviewed argued from a distributional justice standpoint that automobility infrastructure (e.g., roads and tunnels) represents a common good that should be financed entirely by the taxpayer. An interviewed Green Party representative approached the issue from a recognition justice perspective by pointing out that not everyone can afford a car, which indicates that the FNB perspective fails to recognise how funding automobility infrastructure only benefits a select group, making it inherently unfair.

The ruling coalition's reduction of parking spaces in the city aims to level the playing field of convenience and travel time between driving and other modes. Conversion of parking spaces into people-centric land use, e.g., play areas for families, illustrates the car-free socio-technical imaginary championed by the coalition. The FNB representative flagged a distributional effect in this regard, arguing that benefits are concentrated to city centre inhabitants while suburban dwellers bear the burden. The City Council's decision to create CFZs in every suburb can be read partly as a response to such critique. But the FNB representative opined that "people perceive this policy as completely meaningless, provocative and without factual justification. It's this kind of thing that makes people call the Green Party car haters." He elaborated that planners act as though the Bybanen already services these areas (providing a convenient alternative to cars), whereas the light rail line expansion will in fact take many years. This marks a clear bifurcation in mobility imaginaries - car-centric versus commoning oriented - undergirded by divergent socioeconomic visions, justice-related rationales and temporal misalignments.

The Green Party representative posited the reduction of demand for mobility as an important motivating factor for suburban CFZs, noting that the goal is to "fill the street with joy [...] make it nice so people won't feel the need to go 
anywhere." However, if such an approach to demand reduction is accompanied by a failure to simultaneously provide access to low-carbon mobility, there is a risk of socially unjust outcomes such as spatial segregation and unequal access to pursue opportunities closely linked with one's ability to be mobile. Less vocal and organised minorities than pro-car FNB supporters, particularly poor suburban households that cannot afford a car nor housing close to convenient public transport services, are not adequately recognised in the political debate. This despite the fact that support schemes for desirable alternatives to cars, such as subsidies for electric bicycles (and cheaper commuter transport passes in other cities), have proven very popular.

Municipal planners were acutely conscious of these tendencies and the limits that this dominant framing of and contestation over imaginaries placed on their approach to mobility transitions. Planners involved with the Møhlenpris CFZ explained, "we got a lot for free," referring to many organised and engaged groups that were eager to participate in that particular process, ranging from a neighbourhood Action Group and Street Forum to a Somali Women's Group and a Retiree Group. By contrast, they saw the identification of organised neighbourhood groups - or the social construction of these places through a participatory planning exercise - as a major challenge to establish suburban CFZs, without locally established, engaged proponents of the cause.

\section{Discussion: policy insights for a just mobility transition in Bergen}

As our preceding analysis makes evident, Bergen is moving forward with its low-carbon transition, through interventions that are changing the face and functioning of its local transport system. Its inhabitants, their political representatives and urban planners, are constructing, agreeing upon and contesting sociotechnical imaginaries of mobility in which automobility is noisily but steadily being relegated to the back seat, as other modes of transport such as the light rail expand, and yet others including electric buses and a revived tram line emerge. Simultaneously, a powerful EV imaginary is taking hold, extending automobility through perceived compatibility with climate concerns, even as the contrasting project of "commoning mobility" (Nikolaeva et al., 2019) takes a weakened form of articulation as the construction of public spaces for romanticised local togetherness and attachment.

We note that both FNB and the Green Party seem to approach the debate around cars from a justice perspective but ground it in different types of justice. FNB points to distributional justice - arguing to divert the burden of paying for public transport expansion away from financing through toll charges especially into city centres - but neglects the massive investment in car-centric infrastructure funded through the public purse that mainly benefits car users. The Green Party calls for recognition of the "poor" in a Norwegian context - those who cannot afford cars to start with. 
While these competing views and agendas indicate a highly polarised public, our survey responses reveal a much more nuanced and large middle: many people largely support the green imaginary, a strong public transport system and restrictions on private vehicles, but have diverse views on specific interventions (e.g., reduction of parking spaces). As further indicated by our small survey, opinion is not clearly divided between car owners and non-owners. However, the choice of vehicle (fossil fuel versus electric car) and choice of mode (e.g., public transport use when one has a car) reflects some links, albeit tenuous, both to concern for climate change and to financial capacity.

Contradicting views and actions also exist. Two survey respondents indicated a concern with climate in their modal choice, yet reported driving a fossil fuel car and not using public transport. While their reasoning is unknown, we can hypothesise that this is a distributional justice issue related to limited public transport options and the lack of financial means to change vehicles or to move to a location with more convenient access to alternative transport modes. Yet, it is entirely possible that they see their mobility needs as relatively limited and feel entitled to their level of consumption and climate budget despite fossil fuel car use. Rather than black and white relationships to a low-carbon transition, we discern lots of grey zones and nuances. These lived experiences and the contexts that shape perspectives and choices constitute the ground for myriad agreements and contestations with the City Council's socio-technical imaginary of future mobility.

In the midst of this are the planners, who implement this imaginary, with public participation as a tool for recursive alignment with public imaginaries. Yet, the romantic idea of CFZs may be too far removed from a lived reality where people need improved access to low-carbon mobility or are too accustomed to the convenience (and incentivised affordability) of automobility. Mobile subjects may be outraged by the idea that more public space could be linked to reduced demand for mobility (and consequently no improvement in public service provision), making them policy "takers" while those with EVs continue to indulge in automobility with "green buyouts," availing financial incentives from the state (e.g., subsidies, tax exemptions and reduced road tolls) and even free car charging at some workplaces. The stakes in participatory processes are thus high. We foresee the potential risk of a "green backlash" by the poor whom the car-centric stance of FNB does not represent, as the quality of transport services these marginalised users have access to during Bergen's low-carbon mobility transition, if not adequately high, may lead to disillusionment.

Bergen's mobility planners must make a tough choice: if the low-carbon mobility transition is limited to logistical and modal shifts, then suburban CFZs make little sense. Upping the level of ambition to adopt a more aggressive position on place-making that obviates the need for cars and improves public transport service provision to counter critique is the best way forward in this sense. But then, suburban CFZs can be understood as a means of engendering hopeful sociotechnical imaginaries and placing new desirable visions of low-carbon futures in Bergen's outer suburbs, as a "solarpunk" intervention to create real utopias 


\section{Siddharth Sareen et al.}

(Johnson, 2020; Wright, 2010). ${ }^{2}$ Understood thus, suburban CFZs become a matter of demonstrating an attractive alternative future in which cars are side-lined.

The Bergen case shows that, when there are engaged citizen groups calling for low-carbon mobility interventions (as in the CFZ in Møhlenpris), urban planners and policymakers stand to gain by supporting such initiatives and facilitating the materialisation of local, low-carbon imaginaries. These initiatives not only create local benefits, they also strengthen the participatory governance of mobility - commoning both the process and (reclaimed) urban space. Supporting local agency can moreover benefit larger urban transition processes, as it helps demonstrate the potential of such interventions and may well inspire other actors to re-imagine and re-constitute the relationship between mobility, low-carbon transitions, urban space and place-making.

When, and where, such grassroots initiatives and engagement with municipal actors are lacking, a publicly oriented agenda requires policymakers and planners to pay even more attention to divergent imaginaries and uneven distributions of benefits and burdens. This begins with recognising the particular needs and potentials latent in an urban, or suburban, community. This recognition must be followed by participatory planning activities related to place-making that create invited spaces (Gaventa, 2006) to engender and nurture new, publicly oriented imaginaries. This is a form of constructing publics and does not imply control of the public agenda that emerges. Legitimate participation requires delegating power from technocratic decision-makers to publics with their own situated knowledges and imaginaries, while also equipping them with experiences and inputs from policy learning to collaborate on a project of collective improvement. The result is thus steered but not predetermined by visions of experts and policymakers, even when they initiate an intervention.

\section{Conclusion: cross-fertilising insights to Nordic and Baltic cities}

Our mixed methods study of Bergen, a global frontrunner on low-carbon mobility transitions, presents insights on the dynamics and decisions that accompany such shifts. From a policy perspective, cross-fertilisation of such insights is desirable, especially so in Nordic and Baltic urban contexts where similar transitions are already in play or are likely in the near future. Mobility justice scholarship reminds us that these contexts have place-specific legacies to which general justice principles must be applied in situated ways. The main insight with transferable value from our study to Baltic Sea Region contexts is our locally engaged methodology as researchers studying, interacting with and informing public policy on urban mobility transitions. This approach constitutes a mode of generating and inserting insights into public decision-making to advance a twin concern with mobility justice and urban commoning. We offer three generalised reflections that follow from our discussion.

First, despite politically polarised debate, inhabitants' lived experience of mobility is conditioned by complex socio-spatial entanglements, path dependence and individual perspectives, and constitutes a large middle ground. It 
appears that a way forward for urban mobility planners and practitioners is to place trust more firmly in eventual public backing. It seems reasonable to assume that, if they pursue their vision in a manner that creates public value through improved service provision, it will appeal to and be steadily recognised by a large, even if not yet very organised or vocal, user base. As Kębłowski et al. (2019, p. 967) reflect in their study of Tallinn's fare-free public transport scheme, such urban transport interventions are in fact "political and spatial projects, whose processual, cross-sectorial and scalar dimensions help to reveal the embeddedness of transport in inherently urban questions of metropolitan governance, electoral strategies, territorial competition and socio-spatial inequalities."

Second, the rapid growth in EV adoption (a highly incentivised one in a Norwegian context) muddies the waters of low-carbon mobility transitions with elitist options of "green buyout" where relatively well-off households can persist with automobility practices while moving away from fossil fuel cars. This risks losing half the battle of just mobility transitions, as these are a matter of both low-carbon modal shifts as well as reclaiming urban public space. Shifts to EVs must therefore be accompanied by continued phase-out of car parking spaces, more car sharing schemes and a focus on ensuring that the most convenient and affordable option is the public transport system. Light rail expansion along strategic corridors, electrification and expansion of bus fleets, revival of old tramways, bicycle and potentially e-scooter schemes, and improved non-motorised mobility infrastructure are key components here. Such cross-sectoral and socio-spatial considerations are no less important in Baltic Sea Region cities, given their complex histories and resultant forms and political dynamics (Kasekamp, 2017).

Third and last, ambitious visions require inspirational examples. Car-free zoning, if approached as a means to materialise a people-centric form of place-making that "commons" mobility (Nikolaeva et al., 2019) and displaces cars with attractive and inclusive use of public space, can engender public engagement with hopeful socio-technical imaginaries of just mobility futures. Planners must guard against an urban mobility transition being co-opted by elite interests and counter tendencies towards austerity that characterise Baltic Sea Region countries' historical experience (Woolfson and Sommers, 2016) by consistently espousing a broader logic of commoning urban space. If - and only if - implemented in tandem with adequate public transport service provision, such interventions have the potential to succeed not only in central "hipster" neighbourhoods but to lead the transformation of suburban mobility and bring the streets to life by bringing life to the streets.

\section{Acknowledgements}

The authors wish to acknowledge the generous support that made this research possible: the Responsive Organising for Low Emission Societies (ROLES) project funded by JPI Climate through its SOLSTICE call and the Research Council of Norway (grant 321421), as well as the Trond Mohn Foundation's support through the "European cities as actors in climate and energy transformation" project (grant BFS2016REK04). 


\section{Siddharth Sareen et al.}

\section{Notes}

1 Website accessed on 26 March 2021 at https://elbil.no/bergen-er-norges-elbilhovedstad-2018/.

2 Solarpunk refers to the making of hopeful futures, as an aesthetic that stems from an ecologically oriented genre of speculative fiction, and as a socio-politically engaged, reflexively utopian project.

\section{References}

Agyeman, J., Bullard, R.D. and Evans, B., 2002. Exploring the nexus: Bringing together sustainability, environmental justice and equity. Space and Polity, 6(1), Abingdon: Taylor \& Francis, pp. 77-90. DOI:10.1080/13562570220137907

Asdrubali, F., Carrese, S., Patella, S.M. and Sabatini, L., 2018. Development of electric urban mobility: Comparative research and preliminary survey. European Journal of Sustainable Development Research, 2(3), London: Modestum, p. 32. DOI:10.20897/ ejosdr/89694

Axsen, J. and Sovacool, B.K., 2019. The roles of users in electric, shared and automated mobility transitions. Transportation Research Part D: Transport and Environment, 71, Amsterdam: Elsevier, pp. 1-21.

Bergen Municipality, 2019. Municipal county election 2019. Online: https://valgresultat . no/vestland/bergen?type $=$ ko\&year $=2019($ Accessed on 13.03.2021).

Bouzarovski, S. and Simcock, N., 2017. Spatializing energy justice. Energy Policy, 107, Amsterdam: Elsevier, pp. 640-48.

Bullard, R.D. and Johnson, G.S., 2002. Environmentalism and public policy: Environmental justice: Grassroots activism and its impact on public policy decision making. Journal of Social Issues, 56(3), Hoboken: Wiley-Blackwell, pp. 555-78. DOI:10.1111/0022-4537.00184

Croci, E., Lucchitta, B., Janssens-Maenhout, G., Martelli, S. and Molteni, T., 2017. Urban $\mathrm{CO}_{2}$ mitigation strategies under the covenant of mayors: An assessment of 124 European cities. Journal of Cleaner Production, 169, Amsterdam: Elsevier, pp. 161-77.

Doughty, K. and Murray, L., 2016. Discourses of mobility: Institutions, everyday lives and embodiment. Mobilities, 11(2), pp. 303-22. DOI:10.1080/17450101.2014.941257

Eriksen, U., 2020. Et land på fire hjul (A country on four wheels). Res Publica, Oslo, Norway.

Frantzeskaki, N., Broto, V.C., Coenen, L. and Loorbach, D., eds., 2017. Urban sustainability transitions. London: Taylor \& Francis.

Fraser, N., 2009. Scales of justice: Reimagining political space in a globalizing world. New York: Columbia University Press.

Gaventa, J., 2006. Finding the spaces for change: A power analysis. IDS Bulletin, 37(6), Sussex: Institute of Development Studies at the University of Sussex, pp. 23-33. DOI:10.1111/j.1759-5436.2006.tb00320.x

Grava, S., 2007. Urban transport in the Baltic republics. In K. Stanilov, ed., The postsocialist city. Dordrecht: Springer, pp. 313-43.

Haarstad, H., 2019. Do climate targets matter? The accountability of target-setting in urban climate and energy policy. In: Sareen S. (eds), Enabling sustainable energy transitions. Cham: Palgrave Pivot, pp. 63-72.

Hoeschele, W., 2010. The economics of abundance: A political economy of freedom, equity, and sustainability. Abingdon: Routledge. 
IPCC (Intergovernmental Panel on Climate Change), 2018. Global warming of $1.5^{\circ} \mathrm{C}$ : An IPCC special report on the impacts of global warming of $1.5^{\circ} \mathrm{C}$ above pre-industrial levels and related global greenhouse gas emission pathways, in the context of strengthening the global response to the threat of climate change, sustainable development, and efforts to eradicate poverty. Geneva: IPCC.

Jenkins, K., 2018. Setting energy justice apart from the crowd: Lessons from environmental and climate justice. Energy Research $\mathcal{E}$ Social Science, 39, Amsterdam: Elsevier, pp. 117-21. DOI:10.1016/j.erss.2017.11.015

Jenkins, K., McCauley, D., Heffron, R., Stephan, H. and Rehner, R., 2016. Energy justice: A conceptual review. Energy Research $\mathcal{E}$ Social Science, 11, Amsterdam: Elsevier, pp. $174-82$.

Jensen, O.B., 2010. Negotiation in motion: Unpacking a geography of mobility. Space and Culture, 13, Thousand Oaks: SAGE Publishing, pp. 389-402, DOI:10.1177/1206331210374149

Johnson, I., 2020. "Solarpunk" \& the pedagogical value of utopia. Journal of Sustainability Education, 23, Thousand Oaks: SAGE Publishing.

Kasekamp, A., 2017. A history of the Baltic states. Stuttgart: Macmillan.

Kẹbłowski, W. and Bassens, D., 2017. "All transport problems are essentially mathematical": The uneven resonance of academic transport and mobility knowledge in Brussels. Urban Geography, 39, Abingdon: Taylor \& Francis, pp. 413-37. DOI:10.1 080/02723638.2017.1336320

Kẹbłowski, W., Tuvikene, T., Pikner, T. and Jauhiainen, J.S., 2019. Towards an urban political geography of transport: Unpacking the political and scalar dynamics of fare-free public transport in Tallinn, Estonia. Environment and Planning C: Politics and Space, 37(6), Thousand Oaks: SAGE Publishing, pp. 967-84. DOI:10.1177/2399654418821107

Kester, J., Sovacool, B.K., de Rubens, G.Z. and Noel, L., 2020. Novel or normal? Electric vehicles and the dialectic transition of Nordic automobility. Energy Research EO Social Science, 69, Amsterdam: Elsevier, p. 101642.

Köhler, J., Geels, F.W., Kern, F., Markard, J., Onsongo, E., Wieczorek, A., Alkemade, F., Avelino, F., Bergek, A., Boons, F., Fünfschilling, L., Hess, D., Holtz, G., Hyysalo, S., Jenkins, K., Kivimaa, P., Martiskainen, M., McMeekin, A., Mühlemeier, M.S., Nykvist, B., Pel, B., Raven, R., Rohracher, H., Sandén, B., Schot, J., Sovacool, B., Turnheim, B., Welch, D. and Wells, P., 2019. An agenda for sustainability transitions research: State of the art and future directions. Environmental Innovation and Societal Transitions, 31, Amsterdam: Elsevier, pp. 1-32. DOI:10.1016/j.eist.2019.01.004

Loorbach, D., Wittmayer, J.M., Shiroyama, H., Fujino, J. and Mizuguchi, S., 2016. Governance of urban sustainability transitions. Berlin and Heidelberg: Springer.

Markard, J., Raven, R. and Truffer, B., 2012. Sustainability transitions: An emerging field of research and its prospects. Research Policy, 41(6), Amsterdam: Elsevier, pp. 955-67.

Marletto, G., 2014. Car and the city: Socio-technical transition pathways to 2030. Technological Forecasting and Social Change, 87, Amsterdam: Elsevier, pp. 164-78.

Marshall, T., 2016. Prisoners of geography: Ten maps that explain everything about the world. New York: Simon and Schuster.

Martiskainen, M., Sovacool, B.K., Lacey-Barnacle, M., Hopkins, D., Jenkins, K.E., Simcock, N., Mattioli, G. and Bouzarovski, S., 2020. New dimensions of vulnerability to energy and transport poverty. Joule, 5(1), Amsterdam: Elsevier, pp. 3-7. DOI:10.1016/j. joule.2020.11.016 


\section{Siddharth Sareen et al.}

Mattioli, G., Roberts, C., Steinberger, J.K. and Brown, A., 2020. The political economy of car dependence: A systems of provision approach. Energy Research $\mathcal{E}$ Social Science, 66, Amsterdam: Elsevier, p. 101486.

McCauley, D., 2018. Energy justice: Re-balancing the trilemma of security, poverty, and climate change. Cham: Springer International Publishing/New York: Imprint/London: Palgrave Macmillan.

Mullen, C. and Marsden, G., 2016. Mobility justice in low carbon energy transitions. Energy Research Eु Social Science, 18, Amsterdam: Elsevier, pp. 109-17.

Mutter, A., 2019. Mobilizing sociotechnical imaginaries of fossil-free futures-Electricity and biogas in public transport in Linköping, Sweden. Energy Research $\mathcal{E}$ Social Science, 49, Amsterdam: Elsevier, pp. 1-9.

Nikolaeva, A., Adey, P., Cresswell, T., Lee, J.Y., Nóvoa, A. and Temenos, C., 2019. Commoning mobility: Towards a new politics of mobility transitions. Transactions of the Institute of British Geographers, 44(2), Hoboken: Wiley-Blackwell, pp. 346-60. DOI:10.1111./TRAN.12287

Nikulina, V., Simon, D., Ny, H. and Baumann, H., 2019. Context-adapted urban planning for rapid transitioning of personal mobility towards sustainability: A systematic literature review. Sustainability, 11(4), Basel: MDPI, p. 1007. DOI:10.3390/ su11041007

Norsk Elbilforening, 2021. Elbilåret 2020: Desember ble ny rekordmåned [Electric car year 2020: December was a new record month]. Online: https:/elbil.no/elbilaret-2020desember-ble-ny-rekordmaned/ (Accessed on 25.02.2021).

Norwegian Road Federation, 2021. Bilsalget i desember og hele 2020. Online: https://ofv .no/bilsalget/bilsalget-i-desember-2020 (Accessed on 13.03.2021).

Oppedal, L., 2020. Bilfrie soner: Prosjektbeskrivelse [Car-free zones: Project description]. Version 1.0, 23.09.2020. Bergen: Bergen Municipality.

Phdungsilp, A. and Martinac, I., 2013. A proposal of urban district carbon budgets for sustainable urban development projects. In Sustainability in energy and buildings. Berlin and Heidelberg: Springer, pp. 947-54.

Robinson, C. and Mattioli, G., 2020. Double energy vulnerability: Spatial intersections of domestic and transport energy poverty in England. Energy Research ES Social Science, 70, Amsterdam: Elsevier, p. 101699.

Sheller, M., 2018. Theorising mobility justice. Tempo Social, 30, SciELO, pp. 17-34. DOI:10.11606/0103-2070.ts.2018.142763

Sovacool, B., Hook, A., Martiskainen, M. and Baker, L., 2019. The whole systems energy injustice of four European low-carbon transitions. Global Environmental Change, 58, Amsterdam: Elsevier, p. 101958. DOI:10.1016/j.gloenvcha.2019.101958

Sovacool, B.K. and Dworkin, M.H., 2015. Energy justice: Conceptual insights and practical applications. Applied Energy, 142, Amsterdam: Elsevier, pp. 435-44.

Sovacool, B.K., Hess, D.J., Amir, S., Geels, F.W., Hirsh, R., Medina, L.R., Miller, C., Palavicino, C.A., Phadke, R., Ryghaug, M. and Schot, J., 2020. Sociotechnical agendas: Reviewing future directions for energy and climate research. Energy Research EO Social Science, 70, Amsterdam: Elsevier, p. 101617. DOI:10.1016/j.erss.2020.101617

Urry, J., 2006. Inhabiting the car. The Sociological Review, 54, Oxford and Malden: Blackwell Publishing Ltd, pp. 17-31.

Vagnoni, E. and Moradi, A., 2018. Local government's contribution to low carbon mobility transitions. Journal of Cleaner Production, 176, Amsterdam: Elsevier, pp. 486-502.

Van Veelen, B., Pinker, A., Tingey, M., Aiken, G.T. and Eadson, W., 2019. What can energy research bring to social science? Reflections on 5 years of energy research \& 
social science and beyond. Energy Research $\mathcal{E}$ Social Science, 57, Amsterdam: Elsevier, p. 101240. DOI:10.1016/j.erss.2019.101240

Verlinghieri, E. and Schwanen, T., 2020. Transport and mobility justice: Evolving discussions. Journal of Transport Geography, 87, Amsterdam: Elsevier, p. 102798. DOI:10.1016/j.jtrangeo.2020.102798

Waitt, G. and Harada, T., 2012. Driving, cities and changing climates. Urban Studies, 49, Thousand Oaks: SAGE Publishing, pp. 3307-25. DOI:10.1177/0042098012443858

Wood, N. and Roelich, K., 2020. Substantiating energy justice: Creating a space to understand energy dilemmas. Sustainability, 12(5), Basel: MDPI, p. 1917. DOI:10.3390/ su12051917

Woolfson, C. and Sommers, J., 2016. Austerity and the demise of social Europe: The Baltic model versus the European social model. Globalizations, 13(1), Abingdon: Taylor \& Francis, pp. 78-93.

Wright, E.O., 2010. Envisioning real utopias. London: Verso.

Yenneti, K. and Day, R., 2015. Procedural (in)justice in the implementation of solar energy: The case of Charanaka solar park, Gujarat, India. Energy Policy, 86, Amsterdam: Elsevier, pp. 664-73. 